\title{
In-depth Analysis of the Function of College Students' Educational and Aid Work under the Vision of "Precision Poverty Alleviation"
}

\author{
Yuming Zhang \\ Commission of discipline of the China West Normal University, Nanchong 637009, China \\ zhangyuming_160@163.com
}

Keywords: College students, Financing, Educating.

\begin{abstract}
In the new period, it is necessary to pay more attention to physical and mental health of university students and combine the financial support with the spirit support, continuously excavate the fund system's educational function, to explore the path of supporting the system and provide a full support system for supporting the work.
\end{abstract}

\section{Introduction}

Under the environment of "targeted poverty alleviation" in the state, the university funding work is an important part of education poverty alleviation, which plays an important role in promoting the fairness of education and promoting the overall growth of college students. How to guarantee the fairness of education through the funding work, how to make the financing function in place, making the poor students have independent and perfect personality, healthy and positive psychology and correct social values.

\section{Major problems existing in support work of current university students}

\subsection{Cutting the relationship between funding and educating}

Partial pursuiting economic growth, neglecting comprehensive education function, which is one of the main problems of financial support in colleges and universities, the scholar zhen yao points out that, "currently, the financial support system of higher institution focuses on economic compensations, focuses on solving the problems of students' economic problems, and even pays much attention to students to complete more basic studies. however. There is a lack of comprehensive understanding and perspective on the function of the educational assistant, the sustainable development of students and the promotion of comprehensive quality are Less concerned. with the increase of the country's poverty alleviation efforts, education poverty alleviation has been more than unprecedented since the 18th national congress of the communist Party of China. However, the phenomenon of refunding and subsidizing children has not been fundamentally changed, and the relationship between funding and education has been dissected, which has neglected party patriotic and love school education, strenuous enterprising consciousness, free-standing self-improvement consciousness education, thrift, Thanksgiving dedication, honesty aspects such as education for college students, has yet to achieve the purpose of the whole process of all-round education of all students.

\subsection{Cutting the relationship between material financing and psychological support}

At present, the financing of college students has not been done to help the poor before enhancing their willing, that means to support the impoverished college students and to encourage education at the same time, as the content of funding, is an important path to eradicate poverty. But the current funding policy for college students, there is a problem for college students to have an inspirational education, and many college students suffer from the low self-esteem of their families, and they don't want to show their teachers that they have a problem with the family economy, which leads to an aversion to social psychology, which has a profound psychological burden on the long-term, and severe poverty does harm to the mental health of college students. 


\subsection{Cutting the relationship between finance and self-help}

Subsidizing poor college students, if they break the relationship between funding and self-help, they will lead college students to generate ideas that "waitting, wanting, relying". On the one hand, the school attaches great importance to the students' scholarship, financial aid, and even the tuition fee for the students who are struggling with the family financial difficulties. However, for students' self-service behaviors, such as applying for student loans and carrying out work-study programs, the organization promotes the lack of methods, which causes the students' lazy thinking to develop, and the lack of the concept of cultivating students' labor and the idea of entrepreneurship is not good for the healthy growth of college students. therefore, the principle of the combination of paid subsidy (subsidy) and free subsidy (self-help) must be upheld in the construction of the university student financing system in China,, which not only can overcome the shortage of national resources, but also help the college students to solve the economic hardship through their own legal work, and also make their own ability and comprehensive quality be reflected.

\subsection{It is not enough to give precise funding to needy college students}

In recent years, the national funding on the college students pay attention to the accuracy at the same time, but there are some problems, fristly, the lack of precise system of the supported objects, and the support of the country has been continuously increased in recent years, and efforts have been made to meet the original purpose of the students who are not deprived of the family poverty. In the actual operation phase, there are also the poor means of the flood irrigation in the actual operation. In the students, the hidden thoughts such as "rotating on the ground" and the "average distribution", The identification of real poor college students needs to be strengthened, The second is the lack of precision in psychological funding, and poor students tend to have a psychological problem, but the university is not doing a good job with the psychological guidance of the underprivileged.

\section{Analysis on the current financing path for university students}

\subsection{Achieve accurate financing}

Since the 18th congress of the Party, the central party has made a major strategy to alleviate poverty, and Xi general secretary pointed out: to build a well-off society in an all-round way, one cannot little, On the road to prosperity, one cannot be left behind. We need to put in place the precise poverty alleviation and accurate poverty alleviation, so as to achieve to take off the poverty and true poverty alleviation. Education poverty alleviation is an important content of targeted poverty alleviation, and it should also be precise. In the process of funding university students, it is necessary to achieve the precision of financial aid, to change the phenomenon that the poor student status can be proved by a single poverty certificate, and to refer to the daily consumption situation of students, through family visits, and basic knowledge of the basic level, to comprehensively analyze the poverty degree of students' poverty, and ensure the accuracy of the identification of poor students.

\subsection{Achieve the goal of supporting the development of people}

The purpose of the fund is to give poor students a chance to study. In the process of funding, college students in poor receive financial support, psychological counseling and spiritual care, meanwhile, guiding poor college students' patriotic and love school, diligence, frugality, gratitude, etc. education, and translating the economic assistance to difficult students into their understanding, helping, respecting and motivation, satisfying their needs of reality, spiritual needs and self-actualization, and efforts to build a comprehensive, solid form, multi-level and comprehensive financing system based on education, realizing the purpose of educating people.

\subsection{Do the psychological care}

Psychological problems are often associated with poor students, not just to pay attention to poor college student "material poverty", but to pay attention to this part of the student, "mental poverty," to be able to provide the full coverage and precision of the mental health care of the poor students, and in the full coverage, it requires the student's ideological political education, the counselor and the director of the class should pay close attention to the mental health of the poor student, teachers 
should keep that behavior and psychology condition of all the students in poverty, and the precise aspect of psychological care to the mental health of the poor student, the most precise aspect of the mental health, which should ask the high school to do the trick, to distinguish between the different circumstances, to use the form of psychological counseling, the emotional stimulation, the humanistic care, the psychological intervention, the psychological intervention, to eliminate any destabilizing factors.

\subsection{Guide needy college students self-help}

With the expansion of the university, the state's funding has been increasing, but the country's resources are limited, and it's not possible to get any poor students to receive a free national financial aid, but in recent years, the state and universities have been exploring the form of college students, like high school for underprivileged college students to Provide loans, and college students use their spare time, in the case of does not affect the academic, to do some part-time work to subsidize the cost of living in the society, for example,work-study is often in the form of self-serving college students. It is that family 's economic difficulty student who get paid by their own labor to complete their education that can enhance the student' labor consciousness and labor ideas. The work funded by the "blood transfusion" to "Blood type" propulsion, such as the national student loan which means poor students in colleges and universities financial aid work is not only helpful to guide students to establish the concepts of free-standing self-improvement, honest and trustworthy, but also to cultivate the spirit of the students to work hard, and struggling.

\section{References}

[1] Zhen Rao.A study on the construction of a system of education for college students in the field of education [J]. Research on the high education of heilongjiang province, 2014 (2).

[2] Guangdi Feng. The study and strategy of our college students to fund policy [J]. Journal of tianjin normal university (social science edition), 2013 (5).

[3] Bingqi Zhao. The principle and approach of the college poor student financing work [J]. Study on the high education of heilongjiang province,2007, (7): 117.

[4] Huilan Fang. Research on the mental health status of poor students [J]. Journal of Mudanjiang University, 2010, (11) . 